\title{
Teladorsagia circumcincta
}

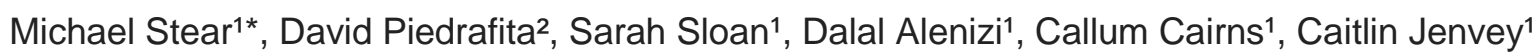

\begin{abstract}
One of the most important parasites of sheep and goats is the nematode Teladorsagia circumcincta. This is common in cool, temperate areas. There is considerable variation among lambs and kids in susceptibility to infection. Much of the variation is genetic and influences the immune response. The parasite induces a type I hypersensitivy response which is responsible for the relative protein deficiency which is characteristic of severely infected animals. There are mechanistic mathematical models which can predict the course of infection. There are a variety of ways to control the infection and a combination of control measures is likely to provide the most effective and sustainable control.
\end{abstract}

\section{Introduction}

Teladorsagia circumcincta is a nematode that parasitises sheep and goats. It was previously known as Ostertagia circumcincta and is colloquially known as the brown stomach worm. It is common in cool temperate areas, such as south-eastern and south-western Australia and the United Kingdom. Teladorsagia davtiani and Teladorsagia trifurcata are probably phenotypic variants (morphotypes) of $T$. circumcincta. ${ }^{[1]}$ This parasite is responsible for considerable economic losses in sheep, ${ }^{[2][3][4]}$ and is believed to cause severe losses in goats although there is a relative dearth of research in goats.

\section{Taxonomy}

Teladorsagia is a member of the subfamily Ostertagiiniae in the family Trichostrongylidae and the superfamily Trichostrongyloidea. ${ }^{[5][6] \quad O s t e r t a g i a, ~}$ Haemonchus and Graphidium are closely related taxa that are usually assigned to separate subfamilies.

\footnotetext{
${ }^{1}$ AgriBio, La Trobe University, Australia

${ }^{2}$ Faculty of Science and Technology, Federation University, Australia

*Author correspondence: m.stear@latrobe.edu.au

ORCID: MS 0000-0001-5054-1348

DP $0000-0001-8692-990 \mathrm{X}$

CJ 0000-0002-4052-4330

Licensed under: CC-BY

Received 09-11-2018; accepted 24-04-2019
}

\section{Morphology}

Adults are slender with a short buccal cavity and are ruddy brown in colour. ${ }^{[7]}$ The average worm size varies considerably among sheep. Females range in size from 0.6 to $1.2 \mathrm{~cm}^{[8]}$ with males typically about $20 \%$ smaller. ${ }^{[7]}$

\section{Life cycle}

The life cycle is relatively simple. Male and female adults breed on the abomasal surface. Eggs are passed in the faeces and develop through first (L1), second (L2) and third stage larvae (L3). Third stage larvae are unable to feed and are the infective stage. Following ingestion,

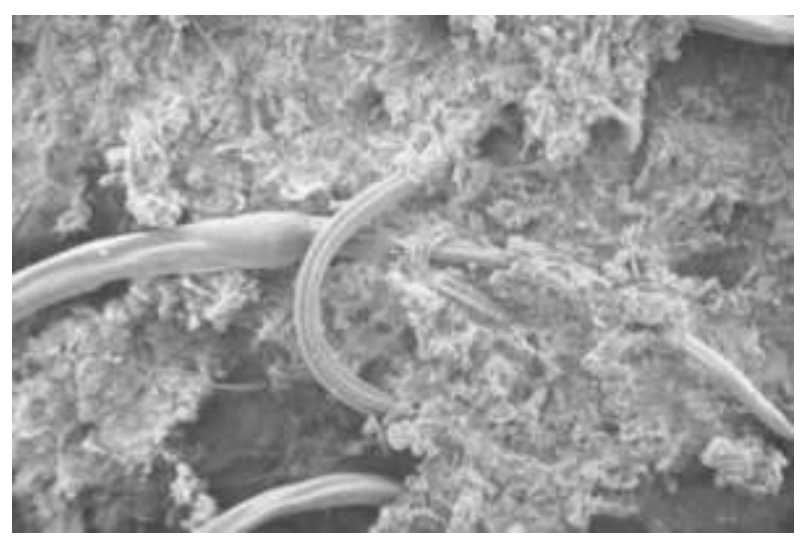

Figure 1 | A scanning electron micrograph of Teladorsagi circumcincta. C.M. Enterocasso, CC BY-SA-2.0 
third-stage larvae rapidly moult within 48 hours into fourth stage larvae (L4) which develop in the gastric glands. About 8 days after infection, the young adults emerge from the gastric glands, mature and breed. The prepatent period can be as short as 12 days. ${ }^{[9]}$ The number of eggs in the uterus of mature females can vary from less than 10 to more than $60^{[9]}$ and is heavily dependent on the host immune response. ${ }^{[10]}$ The number of eggs produced per day by an adult female worm has been estimated as ranging from 0 to approximately $350,{ }^{[10]}$ with longer females laying more eggs. ${ }^{[10]}$

\section{Epidemiology}

In most countries, infection with third-stage larvae resumes in the spring and is triggered by the production of large numbers of eggs by periparturient females. ${ }^{[11]}$ The key trigger appears to be a relative protein deficiency in the ewe ${ }^{[12]}$ and the periparturient rise can be prevented by feeding supplementary protein. ${ }^{[13]}$ In the stereotypical pattern, egg production (assessed by faecal egg counts in the lambs) rises till midsummer then declines. ${ }^{[14][15]}$ The development of free-living nematodes is influenced by temperature and moisture and there is considerable variation within and among among years in the number of infective larvae available for ingestion. Consequently, the pattern of egg production during the year also varies among years. ${ }^{[15]}$ The number of infective larvae gradually dies down at the end of the grazing season when grass growth also declines. The end of the season varies among countries depending upon their climate and is also likely to vary from year to year within countries depending upon local weather but is poorly documented. For example, in Scotland, the season usually ends about late October.

There is considerable variation among animals in faecal egg counts ${ }^{[16]}$ and much of this variation is genetic in origin. ${ }^{[17]}$ The sources of variation are dynamic and their relative importance changes over the course of the year. Other sources of variation, apart from inherited effects include maternal and common environmental effects and effects specific to each individual, including variation in intake and non-additive genetic effects. ${ }^{[16]}$ The gender of the lamb, type of birth (single or twin), date of birth and intensity of early exposure to nematode infection have relatively minor but still important effects. $^{[16]}$ The inevitable variation between the observed count and the true faecal egg count also contributes to the observed variation. ${ }^{[16]}$ Both the natural history of infection and the sources of variation among individuals are relatively well understood for $T$. circumcincta compared to most parasites.

\section{Clinical signs and diagnosis}

Essentially all grazing animals are exposed to infection and most animals will carry some nematodes either as adults or arrested early fourth-stage larvae or both. For disease control, the aim is not to diagnose infection but to identify animals or flocks that are sufficiently heavily infected to show reduced production, decreased animal welfare or parasitic gastroenteritis. Heavily infected animals are relatively protein deficient. Clinical signs include reduced appetite, poor growth performance, weight loss and intermittent diarrhoea. ${ }^{[18]}$ In addition to clinical signs, faecal egg counts and the timing of infection are used to identify severely affected animals. ${ }^{[7]}$ However, lambs with very high numbers of worms produce very few eggs; there are strong densitydependent effects of worm number on egg production. ${ }^{[19]}$

\section{Genetics}

The heritability of a trait in the narrow sense is the proportion of inherited variation divided by the total variation. ${ }^{[20]}$ It determines the response to selection. ${ }^{[21]}$ Faecal egg count is widely used to identify and select animals that are relatively resistant to nematode infection. ${ }^{[22][23][24]}$ Selection is most advanced in Australia and New Zealand where the dominant nematodes are Haemonchus contortus or a mixture of $T$. circumcincta and Trichostrongylus colubriformis.

For naturally infected Scottish Blackface lambs grazing fields contaminated with predominantly $T$. circumcincta eggs, the heritability of faecal egg count was not significantly different from zero for the first two months after birth then rose to approximately 0.3 at the end of the grazing season ${ }^{[25]}$. Similar heritability estimates were obtained for a flock of Texel sheep. ${ }^{[26]}$ This heritability is similar to the heritability of growth rate in beef cattle and milk production in dairy cattle and indicates the feasibility of selective breeding for resistance to natural predominantly $T$. circumcincta infection. ${ }^{[26]}$

Genetic variation in faecal egg count in lambs following natural infection is predominantly due to genetic variation influencing worm size and fecundity rather than worm establishment and survival or larval inhibition. ${ }^{[8]}$ Indeed, the heritability of adult female worm size, 
which is closely related to fecundity, has been estimated at $0.6^{[8]}$ whereas the heritability of worm number was only $0.14 .^{[8]}$ The high heritability of worm size is one of the highest heritabilities known for a fitness related trait.

There has been a lot of effort devoted to identifying the causal polymorphisms that underlie resistance to infection. ${ }^{[27][28]}$ Two genomic regions in particular have shown associations in a number of different studies: the $D R B 1$ locus of the major histocompatibility complex ${ }^{[29][30][33][32][33]}$ and the interferon gamma locus. ${ }^{[34]}$ Linkage disequilibrium in sheep is quite high compared to humans and the causative loci need not be in these regions but are probably in or around these regions. There are a number of regions which have shown suggestive (nearly but not quite statistically significant) associations in more than one study ${ }^{[28]}$ and some of these are probably harbouring causal polymorphisms for nematode resistance.

Many of the putative candidate genes influence the immune response and genetic variation seems to predominantly influence immune responsiveness to infection. Although there are clues that other mechanisms may also contribute to genetic variation. ${ }^{[35]}$

\section{Immune responsiveness}

There are two major manifestations of resistance to $T$. circumcincta: the regulation of worm growth and the control of worm establishment and survival. The regulation of adult worm size and fecundity is strongly and consistently associated with IgA activity especially against fourth-stage larvae. ${ }^{[9][36][37]}$ This effect is so strong and consistent that it is likely causal because there is no other immunological mechanism that is so strongly associated with IgA activity. Eosinophil number is also associated with worm length and fecundity ${ }^{[38]}$ and it is likely that eosinophils and IgA interact to influence worm growth and fecundity. Eosinophils have been implicated in resistance to infection to Haemonchus contortus. ${ }^{[39][40]}$ Eosinophils play a much weaker role in resistance of mice to parasitic infection ${ }^{[41]}$ but this may reflect the fact that mice eosinophils lack the IgA receptor. ${ }^{[42]}$

The other major mechanism of resistance to $T$. circumcincta is the IgE and mast cell mediated control of worm establishment and survival. ${ }^{\left[{ }^{[9]}\right.}$ Again, this association is so strong and consistent that it is likely to be causal rather than acting as a marker for some other response. IgE activity against third-stage larvae seems to be most important. ${ }^{[43][44][9]}$ The number of molecules recognised by IgE seems to be relatively small; two-dimensional Western blotting identified only 9 molecules, although there is evidence for at least two other allergens. ${ }^{[45]}$ For comparison, 155 molecules were recognised by IgA on third-stage larvae. ${ }^{[46]}$

\section{Pathology}

The immune response appears to be responsible for much of the pathology following nematode infection. ${ }^{[18]}$ Immune suppression abolishes many of the clinical signs. ${ }^{[47]}$

Infection causes a relative protein deficiency that leads to reduced weight gain or even weight loss. This due in part to a reduction in appetite. ${ }^{[48][49]}$ There is also a loss in digestive efficiency. Lesions in the epithelial barrier allow a loss of protein and in addition protein is diverted to tissue repair and immune and inflammatory processes. Protein supplementation of the diet can prevent the appearance of clinical signs ${ }^{[48][50]}$ which argues strongly that pathogenesis is a consequence of the relative protein deficiency.

Following infection, there is a breakdown of the mucosal barrier which is a consequence of mast cell degranulation releasing a serine protease mast cell protease II that digests occludin and claudin in the tight junctions between epithelial cells. ${ }^{[18]}$ Many of the pathological responses such as epithelial hyperplasia, increased $\mathrm{pH}$ in the abomasum, pepsinogenaemia and anorexia are a consequence of repair processes triggered by the binding of epithelial growth factor in saliva to receptors on the internal surface of epithelial cells. ${ }^{[18]}$ Prolonged and sustained infection subverts the repair process into a pathogenic mechanism. Mixed infections of abomasal and intestinal species are more pathogenic than monospecific infections, at least in cattle. A plausible explanation is that infection in the small intestine inhibits resorption of proteins lost in the abomasum.

\section{Mathematical modelling}

A number of groups have modelled the infection process ranging from descriptive to semi-mechanistic to almost entirely mechanistic models. ${ }^{[51][52][53][54][55]}$ Initially models were mainly of academic interest but more and more models are playing a useful role in planning experiments. Models can test the hypotheses 
arising from natural and deliberate infections; for example whether genomic approaches can be used to identify animals that do not require anthelmintic treatment ${ }^{[56]}$ and suggest potential strategies for the control of infections. ${ }^{[11][54][56]}$

\section{The control of infection}

The methods to control nematode infection in livestock can be grouped into 6 categories: ${ }^{[57][58]}$ anthelmintic treatment, grazing management, biological control, nutritional supplementation, vaccination and genetic resistance. Each method has its advantages and disadvantages.

Anthelmintic treatment usually involves treatment with one or more of five classes of broad spectrum drugs. drugs: benzimidazoles, levamisole, macrocyclic lactones, amino acetonitrile derivatives and spiroindoles. Narrow spectrum drugs are also available. Drug formulations vary among countries and only some countries allow combinations of drugs to be used. Anthelmintic treatment is cheap, simple and effective but is threatened by the development of drug resistance in parasite populations. ${ }^{[59]}$ There are a number of strategies to mitigate the development of drug resistance including the use of combinations to delay the development of drug resistance in parasite populations. ${ }^{[60]}$ Drugs have been so cheap and effective that it was usually easier and cheaper to treat all animals in a population. However, not all individuals require treatment and best practice is now to target treatment on selected animals to delay the development of drug resistance. The criteria to decide which animals are to be treated and the size of the untreated population are matters of active research. ${ }^{[61]}$

Grazing management usually aims to increase the supply of grass to grazing livestock but can also reduce the numbers of infective nematode available to infect sheep ${ }^{[62]}$. The options include adjusting the stocking density, rotational grazing, the use of less infected pastures, alternating the use of pasture between animals and plants, between different species of animals or between young animals and older stock. ${ }^{[63]}$ Grazing management is cheap, simple and at least some elements are widely used ${ }^{[64]}$ but is seldom very effective in isolation and can be impractical. ${ }^{[62]}$

Biological control with the fungus Duddingtonia flagrans has recently been licensed in Australia and can be very effective ${ }^{[65]}$ but requires regular, possibly daily, feeding.
Nutritional supplementation can eliminate clinical signs but can be very expensive. ${ }^{[66]}$ Supplementation with protein or non-protein nitrogen sources appear more important than supplementation with energy sources. ${ }^{[57]}$ Non-protein sources such as urea are effective $^{[48]}$ and relatively cheap but great care would be needed to avoid toxicity with high doses.

There is currently no completely reliable vaccine but great progress is being made. ${ }^{[67]}$ In general, it is relatively easy to protect older animal but very difficult to protect younger animals. ${ }^{[57]}$

Genetic resistance includes the use of relatively resistant breeds such as the Texel, ${ }^{[31]}$ cross-breeding and selective breeding. Selective breeding can be very effective ${ }^{[24]}$ and almost completely eliminate the need for anthelmintic treatment but requires specialist expertise.

Most experts feel that a combination of control methods will be more effective and sustainable. However, the most effective combination of control methods may vary from farm to farm and require specialist expertise to design and implement.

\section{Additional information}

\section{Competing interests}

The authors have no competing interests.

\section{Ethics statement}

All experiments reported here were approved by the relevant authorities and ethical approval is detailed in the relevant citations.

\section{References}

1. Grillo, Victoria; Craig, Barbara H.; Wimmer, Barbara; Gilleard, John Stuart (2008). "Microsatellite genotyping supports the hypothesis that Teladorsagia davtiani and Teladorsagia trifurcata are morphotypes of Teladorsagia circumcincta". Molecular and Biochemical Parasitology 159 (1): 59-63. doi:10.1016/j.molbiopara.2008.01.001.

2. Nieuwhof, G. J.; Bishop, S. C. (2005). "Costs of the major endemic diseases of sheep in Great Britain and the potential benefits of reduction in disease impact". Animal Science 81 (01). doi:10.1079/asc41010023. ISSN 13577298.

3. Morgan, Eric; Charlier, Johannes; Hendrickx, Guy; Biggeri, Annibale; Catalan, Dolores; von Samson-Himmelstjerna, Georg; Demeler, Janina; Müller, Elizabeth et al. (2013). "Global Change and Helminth Infections in Grazing Ruminants in Europe: Impacts, Trends and Sustainable Solutions". Agriculture 3 (3): 484-502. doi:10.3390/agriculture3030484. ISSN 20770472.

4. Lane, Joe; Jubb, Tristan; Shephard, Richard; Webb-Ware, John; Fordyce, Geoffry (2015). Priority list of endemic diseases for the red meat industries. mla.com.au (Report). Meat \& Livestock Australia Limited. 
5. Hoberg, E. P.; Lichtenfels, J. R. (1994). "Phylogenetic Systematic Analysis of the Trichostrongylidae (Nematoda), with an Initial Assessment of Coevolution and Biogeography". The Journal of Parasitology 80 (6): 976. doi:10.2307/3283448. ISSN 0022-3395.

6. Lichtenfels, J.R.; Hoberg, E.P. (1993). "The systematics of nematodes that cause ostertagiasis in domestic and wild ruminants in North America: an update and a key to species". Veterinary Parasitology 46 (1-4): 33-53. doi:10.1016/0304-4017(93)90046-p. ISSN 0304-4017.

7. Taylor, M. A.; Coop, R. L.; Wall (2007). Veterinary parasitology (3rd ed ed.). Oxford, UK: Blackwell. ISBN 9781118687109. OCLC 842892323.

8. Stear, M. J.; Bairden, K.; Duncan, J. L.; Holmes, P. H.; McKellar, Q. A.; Park, M.; Strain, S.; Murray, M. et al. (1997). "How hosts control worms". Nature 389(6646): 27-27. doi:10.1038/37895. ISSN 0028-0836.

9. Stear, M. J.; Bishop, S. C.; Doligalska, M.; Duncan, J. L.; Holmes, P. H.; Irvine, J.; McCririe, L.; McKellar, Q. A. et al. (1995). "Regulation of egg production, worm burden, worm length and worm fecundity by host responses in sheep infected with Ostertagia circumcincta". Parasite Immunology 17 (12): 643-652. doi:10.1111/j.1365-3024.1995.tb01010.x. ISSN 0141-9838.

10. Stear, M.J.; Bishop, S.C. (1999). "The curvilinear relationship between worm length and fecundity of Teladorsagia circumcincta". International Journal for Parasitology 29 (5): 777-780. doi:10.1016/s00207519(99)00019-3. ISSN 0020-7519.

11. Singleton, D. R.; Stear, M. J.; Matthews, L. (2010-15). "A mechanistic model of developing immunity to Teladorsagia circumcincta infection in lambs". Parasitology138 (03): 322-332. doi:10.1017/s0031182010001289. ISSN 0031-1820.

12. Donaldson, J.; van Houtert, M. F. J.; Sykes, A. R. (1998). "The effect of nutrition on the periparturient parasite status of mature ewes". Animal Science 67 (03): 523-533. doi:10.1017/s1357729800032951. ISSN 13577298.

13. Houdijk, J.G.M; Kyriazakis, I; Jackson, F; Huntley, J.F; Coop, R.L (2000). "Can an increased intake of metabolizable protein affect the periparturient relaxation in immunity against Teladorsagia circumcincta in sheep?". Veterinary Parasitology 91 (1-2): 43-62. doi:10.1016/s0304-4017(00)002557. ISSN 0304-4017.

14. Stear, M. J.; Bairden, K.; Bishop, S. C.; Gettinby, G.; McKellar, Q. A.; Park, M.; Strain, S.; Wallace, D. S. (1998). "The processes influencing the distribution of parasitic nematodes among naturally infected lambs". Parasitology 117 (2): 165-171. doi:10.1017/s0031182098002868. ISSN 0031-1820.

15. Stear, M. J.; Abuagob, O.; Benothman, M.; Bishop, S. C.; Innocent, G.; Kerr, A.; Mitchell, S. (2005-06). "Variation among faecal egg counts following natural nematode infection in Scottish Blackface lambs". Parasitology 132 (02): 275. doi:10.1017/s0031182005009029. ISSN 0031-1820.

16. Stear, M.J.; Park, M.; Bishop, S.C. (1996). "The key components of resistance to Ostertagia circumcincta in lambs". Parasitology Today 12 (11): 438-441. doi:10.1016/0169-4758(96)10069-7. ISSN 0169-4758.

17. Bishop, S. C.; Bairden, K.; McKellar, Q. A.; Park, M.; Stear, M. J. (1996). "Genetic parameters for faecal egg count following mixed, natural, predominantly Ostertagia circumcincta infection and relationships with live weight in young lambs". Animal Science 63 (03): 423-428. doi:10.1017/s1357729800015319. ISSN 1357-7298.

18. Stear, M. J.; Bishop, S. C.; Henderson, N. G.; Scott, I. (2003). "A key mechanism of pathogenesis in sheep infected with the nematode Teladorsagia circumcincta". Animal Health Research Reviews 4 (01): 45-52. doi:10.1079/ahrr200351. ISSN 1466-2523.

19. Bishop, S. C.; Stear, M. J. (2000). "The use of a gamma-type function to assess the relationship between the number of adult Teladorsagia circumcincta and total egg output". Parasitology 121 (4): 435-440. doi:10.1017/S0031182099006526.

20. Falconer, D. S.; Mackay, T. F. G. (1996). Introduction to quantitative genetics. (4th ed.). Essex, England: Longman. ISBN 9780582243026. OCLC 34415160.

21. M., Lynch, (1998). Genetics and analysis of quantitative traits. Sinauer. ISBN 0878934812. OCLC 709410500.

22. Woolaston, R. R.; Windon, R. G. (2001). "Selection of sheep for response to Trichostrongylus colubriformis larvae: genetic parameters". Animal Science 73 (01): 41-48. doi:10.1017/s1357729800058033. ISSN 1357-7298.

23. Bisset, S. A.; Morris, C. A. McEwan, J.C. Vlassof, A. (2001). "Breeding sheep in New Zealand that are less reliant on anthelmintics to maintain health and productivity". New Zealand Veterinary Journal 49 (6): 236-246. doi:10.1080/00480169.2001.36238. ISSN 0048-0169.

24. Karlsson, L. J. E.; Greeff, J. C. (2006). "Selection response in fecal worm egg counts in the Rylington Merino parasite resistant flock". Australian Journal of Experimental Agriculture 46 (7): 809. doi:10.1071/ea05367. ISSN 08161089.

25. Stear, M.J.; Bairden, K.; Bishop, S.C.; Buitkamp, J.; Duncan, J.L.; Gettinby, G.; McKellar, Q.A.; Park, M. et al. (1997). "The genetic basis of resistance to Ostertagia circumcincta inlambs". The Veterinary Journal 154 (2): 111119. doi:10.1016/s1090-0233(97)80049-4. ISSN 1090-0233.

26. Stear, M. J.; Coop, R. L.; Jackson, F.; Bishop, S. C. (2004/04). "Genetic parameters for resistance to nematode infections in Texel lambs and their utility in breeding programmes". Animal Science 78 (2): 185-194. doi:10.1017/S1357729800053972. ISSN 1357-7298.

27. Riggio, V; Matika, O; Pong-Wong, R; Stear, M J; Bishop, S C (2013-20). "Genome-wide association and regional heritability mapping to identify loci underlying variation in nematode resistance and body weight in Scottish Blackface lambs". Heredity 110 (5): 420-429. doi:10.1038/hdy.2012.90. ISSN 0018-067X.

28. Benavides, Magda Vieira; Sonstegard, Tad S.; Van Tassell, Curtis (2016). "Genomic Regions Associated with Sheep Resistance to Gastrointestinal Nematodes". Trends in Parasitology 32 (6): 470-480. doi:10.1016/j.pt.2016.03.007. ISSN 1471-4922.

29. Stear, M.J.; Innocent, G.T.; Buitkamp, J. (2005). "The evolution and maintenance of polymorphism in the major histocompatibility complex". Veterinary Immunology and Immunopathology 108 (1-2): 53-57. doi:10.1016/j.vetimm.2005.07.005. ISSN 0165-2427.

30. Schwaiger, F.-W.; Gostomski, D.; Stear, M.J.; Duncan, J.L.; McKellar, Q.A.; Epplen, J.T.; Buitkamp, J. (1995). "An ovine Major histocompatibility complex DRB1 allele is associated with low faecal egg counts following natural, predominantly Ostertagia circumcincta infection". International Journal for Parasitology 25 (7): 815-822. doi:10.1016/0020-7519(94)00216b. ISSN 0020-7519.

31. Sweeney, T.; Hanrahan, J. P.; Ryan, M. T.; Good, B. (2016). "Immunogenomics of gastrointestinal nematode infection in ruminants breeding for resistance to produce food sustainably and safely". Parasite Immunology 38 (9): 569-586. doi:10.1111/pim.12347. ISSN 0141-9838.

32. Hassan, Musa; Good, Barbara; Hanrahan, James P; Campion, Deirdre; Sayers, Gearoid; Mulcahy, Grace; Sweeney, Torres (2011). "The dynamic influence of the DRB1*1101 allele on the resistance of sheep to experimental Teladorsagia circumcinctainfection". Veterinary Research 42 (1): 46. doi:10.1186/1297-9716-42-46. ISSN 1297-9716.

33. Sayers, G.; Good, B.; Hanrahan, J. P.; Ryan, M.; Angles, J. M.; Sweeney, T. (2005-08). "Major Histocompatibility Complex DRB1 gene: its role in nematode resistance in Suffolk and Texel sheep breeds". Parasitology 131 (03): 403. doi:10.1017/s0031182005007778. ISSN 0031-1820.

34. Coltman, D. W.; Wilson, K.; Pilkington, J. G.; Stear, M. J.; Pemberton, J. M. (2001). "A microsatellite polymorphism in the gamma interferon gene is associated with resistance to gastrointestinal nematodes in a naturallyparasitized population of Soay sheep". Parasitology 122 (05). doi:10.1017/s0031182001007570. ISSN 0031-1820.

35. Hutchings, M.R; Knowler, K.Ji McAnulty, Ri McEwan, J.C (2007-07). "Genetically resistant sheep avoid parasites to a greater extent than do susceptible sheep". Proceedings of the Royal Society B: Biological Sciences 274 (1620): 1839-1844. doi:10.1098/rspb.2007.0398. ISSN 0962-8452.

36. Strain, S. A. J.; Bishop, S. C.; Henderson, N. G.; Kerr, A.; Mckellar, Q. A.; Mitchell, S.; Stear, M. J. (2002). "The genetic control of IgA activity against Teladorsagia circumcincta and its association with parasite resistance in naturally infected sheep". Parasitology $124 \quad$ (05). doi:10.1017/s0031182002001531. ISSN 0031-1820.

37. Martinez-Valladares, M.; Vara-Del Rio, M. P.; Cruz-Rojo, M. A.; RojoVazquez, F. A. (2005). "Genetic resistance to Teladorsagia circumcincta: IgA and parameters at slaughter in Churra sheep". Parasite Immunology 27 (6): 213-218. doi:10.1111/j.1365-3024.2005.00769.x. ISSN 0141-9838.

38. Stear, M. J.; Henderson, N. G.; Kerr, A.; Mckellar, Q. A.; Mitchell, S.; Seeley, C.; Bishop, S. C. (2002). "Eosinophilia as a marker of resistance to Teladorsagia circumcincta in Scottish Blackface lambs". Parasitology 124 (05). doi:10.1017/s0031182002001580. ISSN 0031-1820.

39. González, Jorge F.; Hernández, Álvaro; Meeusen, Els N.T.; Rodríguez, Francisco; Molina, José M.; Jaber, José R.; Raadsma, Herman W.; Piedrafita, David (2011). "Fecundity in adult Haemonchus contortus parasites is correlated with abomasal tissue eosinophils and $\gamma \delta \mathrm{T}$ cells in resistant Canaria Hair Breed sheep". Veterinary Parasitology 178 (3-4): 286-292. doi:10.1016/j vetpar 2011.01.005. ISSN 0304-4017.

40. Meeusen, E.N.T; Balic, A (2000). "Do Eosinophils have a Role in the Killing of Helminth Parasites?". Parasitology Today 16 (3): 95-101. doi:10.1016/s0169-4758(99)01607-5. ISSN 0169-4758.

41. Urban, J. F.; Katona, I. M.; Paul, W. E.; Finkelman, F. D. (1991-01). "Interleukin 4 is important in protective immunity to a gastrointestinal 
nematode infection in mice.". Proceedings of the National Academy of Sciences 88 (13): 5513-5517. doi:10.1073/pnas.88.13.5513. ISSN 00278424

42. van Egmond, Marjolein; Damen, Cora $A_{i}$ van Spriel, Annemiek $B_{i}$ Vidarsson, Gestur; van Garderen, Evert; van de Winkel, Jan G.J (2001). "IgA and the IgA Fc receptor". Trends in Immunology 22 (4): 205-211. doi:10.1016/s1471-4906(01)01873-7. ISSN 1471-4906.

43. Sinski, E.; Bairden, K.; Duncan, J.L.; Eisler, M.C.; Holmes, P.H.; McKellar, Q.A.; Murray, Max; Stear, M.J. (1995). "Local and plasma antibody responses to the parasitic larval stages of the abomasal nematode Ostertagia circumcincta". Veterinary Parasitology 59 (2): 107-118. doi:10.1016/0304-4017(94)00761-z. ISSN 0304-4017.

44. Miller, H.R.P. (1984). "The protective mucosal response against gastrointestinal nematodes in ruminants and laboratory animals". Veterinary Immunology and Immunopathology 6 (1-2): 167-259. doi:10.1016/0165-2427(84)90051-5. ISSN 0165-2427.

45. Murphy, L.; Eckersall, P. D.; Bishop, S. C.; Pettit, J. J.; Huntley, J. F.; Burchmore, R.; Stear, M. J. (2010-17). "Genetic variation among lambs in peripheral IgE activity against the larval stages of Teladorsagia $\begin{array}{lllll}\text { circumcincta". } & \text { Parasitology } 137 & \text { (08): } & 1249-1260 .\end{array}$ doi:10.1017/s0031182010000028. ISSN 0031-1820.

46. Ellis, Samantha; Matthews, Jacqueline B.; Shaw, Darren J.; Paterson, Steve; McWilliam, Hamish E.G.; Inglis, Neil F.; Nisbet, Alasdair J. (2014). "Ovine IgA-reactive proteins from Teladorsagia circumcincta infective larvae". International Journal for Parasitology 44 (10): 743-750. doi:10.1016/j.ijpara.2014.05.007. ISSN 0020-7519.

47. Greer, A.W.; Huntley, J.F.; Mackellar, A.; McAnulty, R.W.; Jay, N.P.; Green, R.S.; Stankiewicz, M.; Sykes, A.R. (2008). "The effect of corticosteroid treatment on local immune responses, intake and performance in lambs infected with Teladorsagia circumcincta". International Journal for Parasitology 38 (14): 1717-1728. doi:10.1016/j.ijpara.2008.05.010. ISSN 0020-7519.

48. Stear, M.J; Bairden, K; Duncan, J.L; Eckersall, P.D; Fishwick, G; Graham, P.A; Holmes, P.H; McKellar, O.A et al. (2000). "The influence of relative resistance and urea-supplementation on deliberate infection with Teladorsagia circumcincta during winter". Veterinary Parasitology 94 (1-2): 45-54. doi:10.1016/s0304-4017(00)00370-8. ISSN 0304-4017.

49. Wallace, D. S.; Bairden, K.; Duncan, J. L.; Eckersall, P. D.; Fishwick, G.; Gill, M.; Holmes, P. H.; McKellar, Q. A. et al. (1998). "The influence of dietary supplementation with urea on resilience and resistance to infection with Haemonchus contortus". Parasitology 116 (1): 67-72. doi:10.1017/s0031182097001947. ISSN 0031-1820.

50. Coop, R.L.; Kyriazakis, I. (1999). "Nutrition-parasite interaction". Veterinary Parasitology 84 (3-4): 187-204. doi:10.1016/s03044017(99)00070-9. ISSN 0304-4017.

51. Smith, G.; Grenfell, B.T. (1994). "Modelling of parasite populations: gastrointestinal nematode models". Veterinary Parasitology 54 (1-3): 127143. doi:10.1016/0304-4017(94)90087-6. ISSN 0304-4017.

52. Bishop, S. C.; Stear, M. J. (1997). "Modelling responses to selection for resistance to gastro-intestinal parasites in sheep". Animal Science 64 (03): 469-478 doi:10.1017/s1357729800016088. ISSN 1357-7298.

53. Doeschl-Wilson, Andrea; Vagenas, Dimitrios; Kyriazakis, Ilias; Bishop, Stephen (2008). "Exploring the assumptions underlying genetic variation in host nematode resistance (Open Access publication)". Genetics Selection Evolution 40 (3): 241. doi:10.1186/1297-9686-40-3-241. ISSN 1297-9686.

54. Prada Jimenez de Cisneros, J.; Stear, M. J.; Mair, C.; Singleton, D.; Stefan, T.; Stear, A.; Marion, G.; Matthews, L. (2014-13). "An explicit immunogenetic model of gastrointestinal nematode infection in sheep".
Journal of The Royal Society Interface11 (99): 20140416-20140416. doi:10.1098/rsif.2014.0416. ISSN 1742-5689.

55. De Cisneros, Joaquin Prada Jimenez; Matthews, Louise; Mair, Colette; Stefan, Thorsten; Stear, Michael J. (2014-13). "The transfer of IgA from mucus to plasma and the implications for diagnosis and control of nematode infections". Parasitology 141(07): 875-879. doi:10.1017/s0031182013002321. ISSN 0031-1820.

56. Laurenson, Yan C.S.M.; Kyriazakis, Ilias; Bishop, Stephen C. (2013). "Can we use genetic and genomic approaches to identify candidate animals for targeted selective treatment". Veterinary Parasitology 197 (1-2): 379-383. doi:10.1016/j.vetpar.2013.04.039. ISSN 0304-4017.

57. Stear, M. J.; Doligalska, M.; Donskow-Schmelter, K. (2006-01). "Alternatives to anthelmintics for the control of nematodes in livestock". Parasitology134 (02): 139. doi:10.1017/s0031182006001557. ISSN 00311820.

58. Sayers, G.; Sweeney, T. (2005). "Gastrointestinal nematode infection in sheep - a review of the alternatives to anthelmintics in parasite control". Animal Health Research Reviews 6 (02): 159-171. doi:10.1079/ahr2005108. ISSN 1466-2523.

59. Bartley, D.J.; Jackson, F.; Jackson, E.; Sargison, N. (2004). "Characterisation of two triple resistant field isolates of Teladorsagia from Scottish lowland sheep farms". Veterinary Parasitology 123 (3-4): 189-199. doi:10.1016/j.vetpar.2004.06.018. ISSN 0304-4017.

60. Leathwick, D.M.; Besier, R.B. (2014). "The management of anthelmintic resistance in grazing ruminants in Australasia-Strategies and experiences". Veterinary Parasitology 204 (1-2): 44-54. doi:10.1016/j.vetpar.2013.12.022. ISSN 0304-4017.

61. Kenyon, F.; Greer, A.W.; Coles, G.C.; Cringoli, G.; Papadopoulos, E.; Cabaret, J.; Berrag, B.; Varady, M. et al. (2009). "The role of targeted selective treatments in the development of refugia-based approaches to the control of gastrointestinal nematodes of small ruminants". Veterinary Parasitology 164 (1): 3-11. doi:10.1016/j.vetpar.2009.04.015. ISSN 03044017.

62. Gruner, Lucas; Cortet, Jacques; Sauvé, Christine; Hoste, Hervé (2004). "Regulation of Teladorsagia circumcincta and Trichostrongylus colubriformis worm populations by grazing sheep with differing resistance status". Veterinary Research35 (1): 91-101. doi:10.1051/vetres:2003043. ISSN 0928-4249.

63. Stear, M. J.; Doligalska, M.; Donskow-Schmelter, K. (2006-01). "Alternatives to anthelmintics for the control of nematodes in livestock". Parasitology 134 (02): 139. doi:10.1017/s0031182006001557. ISSN 00311820.

64. Gettinby, G.; Armour, J.; Bairden, K.; Plenderleith, R. (1987-21). "A survey by questionnaire of parasitic worm control in cattle and sheep at the Glasgow University Lanark practice". Veterinary Record 121 (21): 487-490. doi:10.1136/vr.121.21.487. ISSN 0042-4900.

65. Waller, P.J.; Schwan, O.; Ljungström, B.-L.; Rydzik, A.; Yeates, G.W. (2004). "Evaluation of biological control of sheep parasites using Duddingtonia flagrans under commercial farming conditions on the island of Gotland, Sweden". Veterinary Parasitology 126 (3): 299-315. doi:10.1016/j.vetpar.2004.08.008. ISSN 0304-4017.

66. Coop, R.L.; Holmes, P.H. (1996). "Nutrition and parasite interaction". International Journal for Parasitology 26 (8-9): 951-962. doi:10.1016/s0020-7519(96)80070-1. ISSN 0020-7519.

67. Nisbet, Alasdair J.; McNeilly, Tom N.; Greer, Andrew W.; Bartley, Yvonne; Oliver, E. Margaret; Smith, Stephen; Palarea-Albaladejo, Javier; Matthews, Jacqueline B. (2016). "Protection of ewes against Teladorsagia circumcincta infection in the periparturient period by vaccination with recombinant antigens". Veterinary Parasitology 228: 130-136. doi:10.1016/j.vetpar.2016.09.002. ISSN 0304-4017. 